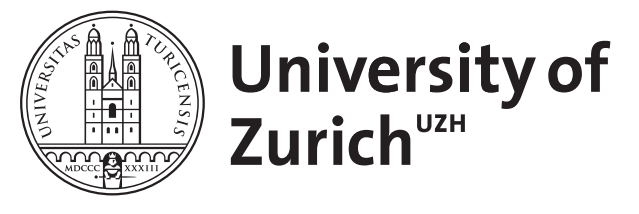

\title{
Platonische Aufsätze
}

Ferber, Rafael

\begin{abstract}
Der Band enthält eine Auswahl von Aufsätzen zu Platon von seinen sokratischen Anfängen bis zu seiner Nachwirkung bei Donald Davidson und Hans-Georg Gadamer. Ein besonderes Augenmerk liegt auf der Problematik der Idee des Guten und der Frage ihrer Transzendenz und Immanenz. The volume contains a selection of essays on Plato from his Socratic beginnings to his aftermath in the works of Donald Davidson and Hans-Georg Gadamer. Particular attention is paid to the Idea of the Good and the question of its transcendence and immanence.
\end{abstract}

DOI: https://doi.org/10.1515/9783110637601

Posted at the Zurich Open Repository and Archive, University of Zurich

ZORA URL: https://doi.org/10.5167/uzh-187958

Monograph

Supplemental Material

Originally published at:

Ferber, Rafael (2020). Platonische Aufsätze. Berlin / Boston: Walter de Gruyter.

DOI: https://doi.org/10.1515/9783110637601 


\section{Platonische Aufsätze}

Rafael Ferber, Platonische Aufsätze. Beiträge zur Altertumskunde, 386. Berlin; Boston: De Gruyter, 2020. Pp. x, 400. ISBN 9783110633344 \$103.99.

\section{Review by}

Miquel Solans, University of Navarra. msolans@unav.es

\section{Table of Contents}

Platonische Aufsätze ('Platonic essays') contains a selection of 18 papers (12 in German and 6 in English) on Plato's philosophy and its reception, written by Rafael Ferber over the last 30 years. Many of these works were presented and discussed at various Platonic conferences. All contributions, with the exception of chapter 10, have already been published. The versions presented in this volume have been revised and, in some cases, extended, the secondary literature has been updated to a certain extent, and useful abstracts have been added at the beginning of each chapter. The book offers a valuable overview of the author's approach to Plato, which effectively combines erudition and philosophical depth. Space limitations make it impossible to give due attention to each one of the papers. So, in what follows, I shall summarize the main contents of the work and discuss some of its most significant contributions.

The book can be loosely divided into five thematic sections. After a first short chapter on the connections between Plato's Apology, Gorgias' Defence of Palamedes and Euripides' Hippolytus, chapters 2 to 5 (though, unfortunately, the reader will find no chapter numbers in the book) discuss Plato's account of knowledge and virtue in the early and middle dialogues. In this section, Ferber offers a distinctive interpretation of Socrates' knowledge in light of the simile of the line in the Republic. According to the author, what Socrates knows can be summarized in a 'central core' of seven theses: there is a difference between knowledge and correct opinion; it is better to suffer injustice than to commit it; for the unjust, it is better to be punished than to escape punishment; the just man is happy, whereas the unjust is unhappy; virtue is knowledge; no one commits injustice voluntarily; and the pleasant is not the good (39). The author's view - original, as far as I know - is that the epistemic status of those seven pieces of Socratic knowledge is 'quasi-dianoetic', for these logoi do not rely on empirical knowledge (empirisches Wissen), but on rational grounds (Vernunftgründe) (40). This is shown by the fact that these truths are established through the practice of Socratic elenchus, aimed at ensuring coherence in the use of concepts. For instance, from a coherent and not-contradictory use of the term 'knowledge' it follows that knowledge is not the same as correct opinion; and from the coherent and not-contradictory use of 
'virtue' it follows that virtue is knowledge (41). The truth of these conclusions, then, corresponds to that of agreements reached by Socrates and his interlocutors after 'elenctic' purification of incoherent and contradictory usages of those concepts in ordinary language. Therefore, the seven theses of the central core of Socrates' knowledge should be considered as conceptual truths (begriffliche Wahrheiten) (ibidem), for Socrates considers that the absence of contradiction (Wiederspruchsfreiheit) is both necessary and sufficient condition for their truth (ibidem). In relation to the divided line, Ferber argues that Socrates' seven theses are of the same epistemological kind as the hypotheseis of the mathematicians, since they are not secured by direct or noetic knowledge, but by agreements reached by Socrates and his interlocutors on what the best presuppositions are, and therefore by dianoetic knowledge (50-53). A detailed evaluation of this reading is far beyond the scope of this review. From a general perspective, however, one interpretative advantage of Ferber's reading is that it dissolves the apparent and much discussed contradiction between Socrates' recurring disavowals of knowledge throughout the dialogues and his already mentioned knowledge-claims (the central core): while the former refer to a lack of noeticknowledge, the latter indicate the possession of dianoetic knowledge.

The next three chapters (6-8) deal with the epistemological and ontological status of the idea of the good in the Republic. Ferber distinguishes three groups of interpretations: the 'henological', according to which the idea of the Good transcends not just the world of experience, but also the realm of ideas; the 'perfectionist', that sees the idea of the good as an ens perfectissimum that constitutes the ground of the essence of the rest of ideas; and the 'structuralist', in which the idea of the Good corresponds to the teleological structure of forms (108). Despite its irreducible differences, synthesized by Ferber in the form of a 'trilemma', all three readings accept that the good is a 'third thing' between knowledge and being. The Good, thus, is per se beyond the field of our personal experience, but at the same time it is guessed or divined (apomanteuesthai) by our soul. Here we find, according to the author, an inner tension that pervades the Platonic treatment of the Good: a tension between the principle of the priority of the definitional knowledge of the good, on the one hand, and Socrates' recognition that he only has an unproved opinion about the Good (111), on the other. This is closely connected with the transcendent character of the Good, discussed by Ferber in chapters 7 and 8, which implies that it cannot be directly known. Given that our knowledge is mediated by language, it necessarily entails a 'doxastic moment' (doxastische Moment) that makes it impossible to have a direct grasp of the idea of the Good (134). This is why, while Socrates can speak in the three similes of the sun, the line, and the cave, about the effects of Good on us, he cannot specify its content. Now, this fact may well indicate that the idea of the Good falls completely beyond our possible experience, as Ferber seems to assume, but it can also suggest that our knowledge of the Good corresponds to a form of access categorically different from definitional knowledge, as some authors propose. In this sense, and given that references to Kant and the Kantian tradition are not rare in the present book (see, for instance, 193), a comparison with Herman Cohen's and 
Wolfgang Wieland's interpretation of the idea of the Good in terms of the Kantian faculty of judgment - not reducible to any of the three interpretative lines mentioned above - would have been very productive.

Chapters 9 and 15 focus on the long-disputed issue of Plato's unwritten doctrines. Though various lines of interpretation are discussed, the author's main theses in both chapters are established in dialogue with Hans Krämer, one of the leading figures of the Tübingen School. As is well known, Krämer argues that Plato's unwritten doctrines contain a closed system of philosophical axioms and, accordingly, that Plato claimed to possess a final and most secure form of knowledge. While Ferber believes in the existence of unwritten doctrines, he nevertheless denies, drawing on the epistemology of the Seventh Letter (264), that they correspond to some sort of definitive systematic knowledge. In line with this, he claims that the reason why Plato did not write the unwritten doctrines does not lie in the conditions required by the subject-matter for its communication, as Krämer argues, but in the fact that the Platonic Socrates does not possess definitive knowledge of how things are, and the inflexible character of the written word is false to the responsive nature of progress in suchknowledge (164). On the other hand, however, Ferber also rejects the purely skeptical picture of Plato's thought. The Greek philosopher did not claim to have arrived at the final truth, but he nevertheless claimed that truth can be known (269). As far as I see, the decisive philosophical point in this 'approximativist' approach (Approximativismus, as the author calls it) is the claim that Plato's philosophy does not rest on any unconditional starting point (vorausetzungsloser Anfang), but precisely on the presupposition of ideas and principles as well as truth as the ultimate aim of our knowledge (269 and 260).

Plato's late dialogues are the object of chapters 10 to 14. Chapter 10 deals with the Theaetetus and discusses the topic of the homoiôsis theô( $i)$ in the context of Plato's treatment of the Protagorean thesis of the homo mensura. According to Ferber's reading, and in line with the approximativism mentioned before, assimilation to God refers to the gradual approximation of our knowledge to God's knowledge (176). Centered on the Philebus, chapter 11 explains why the Goodis referred to as only one (semantic monism) and, at the same time, it is referred to as 'beauty, symmetry and truth' (Philebus 65a) (semantic pluralism). Ferber's suggestion is that the last three references are 'qualities' (poia) of the one single reference. Chapter 12 presents a propaedeutic reading of the Statesman, according to which the aim of the dialogue is the philosophical education (philosophische Bildung) of the reader. More precisely, the dialogue is to be seen as a preparation for the correct understanding of the doctrine of ideas and for the 'exposition of the exact itself' (peri auto takribes apodeixis), the Good (211). In chapter 13, Ferber argues that the argument for the existence of ideas in the Timaeus (51d-52a) escapes the criticism of ideas in the Parmenides. While in the Parmenides sensible phenomena are seen as substantial entities, in the Timaeus, sensibles are qualities of space (227). As qualitative entities, sensibles possess a purely relational being, and so they cannot be properly accounted for through the subject-predicate structure (229). 
Sensibles are relational imprints (relationale 'Abdrücke') of the corresponding ideas (230). Finally, chapter 14 advocates for a 'continuist' reading of Plato's Republic, Statesman and Laws.

The last section of the volume (chapters 16-18) discusses the reception of Plato in Aristotle, Kant, Gadamer and Davidson. The reader will find all three contributions highly informative and many of their theses philosophically challenging (especially chapter 16, where the author critically approaches Aristotle's theory of substance).

All in all, Rafael Ferber's approach to Plato's philosophy is a remarkable combination of philological rigor, a comprehensive and open-minded treatment of the secondary literature (in German, English, French and Italian), argumentative clarity and philosophical audacity. In this sense, an unusual and refreshing feature of this book is that it does not present Plato's philosophy only as a historical object of analysis, but also as a lively, thought-provoking contribution to current philosophical concerns.

The book, published in the well-reputed series Beiträge zur Altertumskunde, is carefully edited. I noticed only three small typos in this long volume.[1] At the end, the reader is presented with a detailed selection of topics divided by chapters. The work is closed by a list of references and three helpful indexes (locorum, rerum and nominum).

\section{Notes}

[1] P. 227, n. 31: 'Identität' instead of 'Identität'; p. 259: 'philosopischer' instead of “philosophischer”; p. 263: 'Spinozaswohl' instead of 'Spinozas - wohl'. 